\title{
Milliequivalent per Milliliter
}

National Cancer Institute

\section{Source}

National Cancer Institute. Milliequivalent per Milliliter. NCI Thesaurus. Code C73737.

A concentration unit expressed in milliequivalent(s) of solute per milliliter of solution. 